\title{
Child Poverty and Food Scheme in Rural South African Schools: The Prospects and Limits Towards Improving the Emotional Well- Being of the Elementary School Students
}

\author{
Prince Amartey Mensah, Dr. Felix Ifeanyichukwu Okoye \\ BSc. Agric Eng. (degree); \\ Post-graduate Certificate in Education (PGCE); \\ Master of Education (M. Ed). \\ B.A; Phil; SocSc (honours) in Policy \& Dev. \\ M.Ed. \& Ph.D. in Education \& Dev. \\ DIRAP research member: University of The Free State.
}

\begin{abstract}
:
The research examines the impact of poverty on the emotional well-being of elementary school students in South African rural communities. In order to understand this phenomenon, the study investigates the question on: how does poverty affect the emotional well-being of elementary school students in South Africa? The non-empirical study explores the literature from related studies to answer the research question. The literature review critically examines the effect of poverty on the emotional well-being of children, as well as the strategies used by the government to alleviate the poverty impact at rural school children. The strategies were found to have implementation deficiencies which enables the researcher to argue on the importance of improving the implementation strategies. The finding also reveals that despite the government's interventions to curb the problem of child poverty, yet there are policy implementation 'gaps' here and there. The study recommends more study and consistent evaluation of the respective policy framework. It also recommends that the socio-economic status of people leaving in the rural area should be improved and the affected students should be engaged, and proper development response should be executed to guarantee a sustainable food security. The study concluded that more study and consistent evaluation of the feeding-scheme programme or policy is a sinequanon. The Covid-19 recommendations are added for publication purposes.
\end{abstract}

Keywords: Food-scheme policy, child poverty, school children, rural schools, emotional well-being, improvement strategy, academic challenges, policy interventions, hunger, deprived homes, elementary schools

\section{Introduction}

The political past of South Africa has left a legacy of poverty to a certain population described as previously disadvantaged (Fick, 2017). In this hard time, poverty has become a consistent 'thug of war' with risk factors which is critically affecting children mentally, physically and emotionally in South Africa (Ebersohn, 2017). The definition of poverty describes lack of income and inability to have supplements for the sustenance of other miscellaneous factors (Black \& Engle, 2008; Pearce, 2016). Poverty has affected the well-being of school children consequently the teachers' effort is neutralized by poverty effects on school children which include sleeping during lessons, unable to meet due dates for their assignments, lack concentration during lesson, irregularity and punctuality to school, absenteeism and other possible physical factors. The research is based in Kwazulu-Natal province of South Africa. The province known for its escalating poverty rate and HIV/AIDS. The growing socio-economic deficiency leaves children from this province with a "poverty gap" which may take a long time to overcome (Pearce, 2016). Depression and 
stress constitutes the most poverty effects that increasingly affect the children physically and destabilize their emotional well-being (Ebersohn, 2017). The government's efforts and contributions to eradicating poverty effects remains unrealistic. According to Ebersohn (2017), most children in South Africa hardly meet the three-square meals daily. The parents are both unemployed, and their salary is insufficient to cater for the needs at home. The children from poor homes seem to have more worries and unfulfilled social needs which affect their performance (Black \& Engle, 2008; Ebersohn, 2017). Poverty can have long-lasting effects on children emotionally, academically and environmentally (Pearce, 2016). Despite government's effort to assist in resolving the problem there are still extreme cases (Fick, 2017). The psychological and physiological needs of the children require government's immediate attention as it creates confusion, worry, tension and result in performance deficiencies (Tissington, Laura, \& Lacour, 2011). The rationale behind this study stems from a personal observation as an experience teacher with long-service history in South African rural school. I noticed that the children from poor backgrounds depend completely on the government supplies for survival. Most parents cannot assist in areas where government provisions are insufficient, and this situation breaks my heart. There is also an increasing deterioration and deficiencies in implementation of poverty alleviation strategies in schools and rural communities in South Africa. This problem requires an urgent development and policy intervention to avert its future catastrophe to the country's education and economy. The non-empirical research study aims to investigate the impact of poverty on the emotional well-being of elementary students in South African rural schools. It critically examines the existing literature and studies in this topic to answer the key research question of: how does poverty affect the emotional well-being of elementary school students in South Africa? In order to adequately answer the key question, I intended to explore the following objectives (1) the impact of poverty on the emotional well-being of elementary school children in South African rural schools; (2) to understand how the poverty alleviation strategies in schools has been implemented for curbing of poverty; (3) to investigate the limitations of the feeding scheme implementation strategies; and (4) to suggest plausible measures to improve classroom teaching and learning of the rural communities in KwaZulu-Natal. In order to achieve the objectives, the following sub-research questions were applied to ensure that the key research question is adequately answered. (1) What are the effects of poverty on the emotional well-being of elementary school students? (2) How effective are the poverty alleviation strategies in reducing the poverty effects on the emotional well-being of school children? (3) What are the limitations the poverty alleviation strategies to the well-being of the students? And (4) how can these strategies be improved to ensure equity and excellence for all students in the classroom? It is important to mention that the understanding of the concept 'poverty' and 'emotional well-being' are imperative to this study.

\section{Poverty And Emotional Well-Being Of School Children:}

What is emotional well-being? The concept emotional well-being as used in this treatise refers to the state of mind of a person which assists and enables them to concentrate, focus and process real life situations (Pearce, 2016). The 'well-being' of a person is referred to how one conducts himself or herself in terms of emotional combat and ability to avert destruction and conscious endeavors that can be described as behavioral negativities of life (Tang et al., 2016; Global partnership for education, 2017). The emotional well-being is all about the frame of mind of a person (Dike, 2017). The brain is a place of storage where information is stored, its function is destabilized or traumatized whenever the body feels shock or anxiety. This may reduce the rate at which children can contribute to their classroom effectiveness and performance (Dike, 2017). According (Tang et al., 2016), the children from poor homes lack emotional support which is transferred to their basic experiences more especially classroom achievement. The judgmental thoughts of such children are limited, inconclusive and poor which further creates a mild stress level causing them to feel uncomfortable and rejected. Such students often resort to smoking and drinking due to emotional discomfort (Tang et al., 2016). Recently, there was a reported case of matriculates who were drunk because they had a problem with low shedding (or incessant power failure) during the examination period and could not revise their subjects before writing. The healthy mind from a well-organized home is very necessary for the accessibility and successful classroom activities and participation to ensue (Tang et al., 2016).

According to Ebersohn (2017), unemployment is the backbone of poverty in the rural areas in KwaZuluNatal. The children of the unemployed parents face abject poverty, although the parent may be grant recipients, but the grant is very little. Carey (2014) asserts that children between the ages of four to ten years are not emotionally matured to handle situations of poverty like their parents. Thus, their thinking faculty is 
undeveloped to maneuver decisions that produce integrity, honesty and good morals. The down-syndrome experienced by the affected children includes the decision to leave home for street life as street kids, to become vender, or drug peddlers (Carey, 2014). The children from such poor homes often sleep on empty stomach and the hippocampus which deals with memory control become disorganized (Carey, 2014).

What is poverty? In this study's context poverty implies not having enough money for basic needs such as food, water, shelter or toilets. According to Woolfolk (2016), in the article titled "Poverty and Brain Development in Children: Implication for learning" Woolfolk corroborated the claim that poverty has a direct correlation to brain function of a child. Such that the longer the child experience low balance diet the more he or she gets disorientated (Woolfolk, 2016). The deprivation of basic amenities such as running water, electricity, good roads, and lack of corridors that are job intensive, neutralizes the teachers' efforts, as well as exacerbate issues of: late-coming, poor performance, late submissions, absenteeism, irregularity and punctuality (Mueller, Bovard \& Ferguson, 2007; Ebersohn, 2017). One may agree that the feeding scheme policy framework was a step-in right direction for South Africans. It is understandable that the government has handful of other projects to undertake but should not be a reason for the lack of upgrade, monitoring and evaluation of the feeding scheme policy. The limited resource availability too does not qualify as a cogent reason for government's tacit response or irresponsiveness towards the feeding scheme deficiency.

The South African political past has left a legacy of poverty to certain population described as previously disadvantaged. This population consists of the today's black South Africans which constitute 79\% of the national population (Ebersohn, 2017). Statistically, over half of South African population is living in poverty (Statssa, 2016). The poverty report indicates that between 2006 and 2015 over 30.4 million people were living in poverty which is approximately $53,2 \%$ of the population (Statssa, 2016). It has increased over time from 53, $2 \%$ to $55,5 \%$ (Omarjee, 2017). Hence, students from poverty homes lack the peace, love and care needed for the generation of ideas which may come from the lack of parental support and resources. Unfortunately, many children from rural disadvantaged communities trek to school without breakfast and in tattered clothes (Tang et al., 2016). According to Tang et al. (2016), the breakfast is the most important meal of the day. Experience has shown that students often report to school with various diseases such as headache and stomachache which end up leaving some of them hospitalized. The longer the child experience poverty the more grievously the child's academic performance is being affected (Woolfolk, 2016). For instance, the students from poor homes are unable to connect effectively with friends and teachers which sometime leads to a low self-esteem or depression. The hungry students from poor background get irritated and furious easily making it difficult for the teacher to deal with them in the classroom. Anxiety is a great impediment to learning especially to children at their elementary level (Okoye, 2013).

Taylor \& Servass van der Berg Ronelle Burger (2011) in a research study titled "low-quality education as a poverty trap in South Africa" emphasized that poverty targets some schools more than the others. The South African education system consists of three types of schools: independent schools (or private), government schools and governing body-funded public schools (Taylor \& Servass van der Berg Ronelle Burger, 2011). Private schools are far more expensive than public education often because they offer exceptional standards. The private schools are attended mostly by children from middle-and high-income families. The Former Model C schools are government schools that are administrated and largely funded by a governing body of parents and alumni (Taylor \& Servass van der Berg Ronelle Burger, 2011). Some of the country's best schools fall into this category, and fees are somewhere between private and regular government school fees. The government schools are controlled by provincial education departments and the standards or output vary widely (Ebersohn, 2017). Public schools in KwaZulu-Natal depend solely on the government for funding and supplies. Each province has the responsibility to ensure that the schools are equipped and have sufficient money to run properly. As a result, the standards vary immensely depending on the efficiency and wealth of the province (Nhlapo et al., 2015).

Nevertheless, due to inadequate funding and monitoring from the government, many children from rural areas receive low standards of education through a lack of qualified teachers and sometimes an outright absence of learning equipment in the classrooms (Ebersohn, 2017). Due to these shortcomings, the parents who can afford private school fees do send their children to private schools. In cities, public school standards are generally better (Ebersohn, 2017). Public schools located in cities draw students and funding from their suburbs irrespective of its private competitors. The best government schools in Kwazulu-Natal are partially administrated and funded by parents and a governing body usually known as "Model C" schools (Taylor \& Servass van der Berg Ronelle Burger, 2011). Whilst many private schools have religious 
origins and aim to provide pupils with spiritual foundation to complement their academic and physical accomplishments. Some private schools have better facilities, smaller classes and a larger selection of extracurricular (or sport) activities (Ebersohn, 2017). Recent studies have linked poverty to poor learning in rural schools (Murname, 2007; Kubitschek \& Hallinan, 2010; Taylor \& Servass van der Berg Ronelle Burger (2011); Gorski, 2013; Okoye, 2013, Hewitt, 2016; Ebersohn, 2017). The state of rural schools in South Africa is a concern (Kubitschek \& Hallinan. 2010; Ebersohn, 2017; Hewitt, 2011). For instance, the schools are populated such that the supply by the government does not meet their demands (Ebersohn, 2017). The parents are forced to meet the government half-way even though some of these parents are unemployed and could not help themselves. This create challenges such as children being exempted from school by mostly unemployed parents to stay at home to avoid the financial burden from the school (Ebersohn, 2017; Hewitt, 2016). The children walk long distances to school and mostly miss the first period and sometimes second period (or lesson). Hence, the missing of class activities precipitates poor performance, uncompleted schoolwork or withdrawal from learning activity which is evident in South African schools (Gorski, 2013). The parents of these children are uneducated and hardly attend school workshops and meeting as such the performance of their children are of little concern to them (Hewitt, 2016) this however constitutes a larger discrepancy to the annual recording sheets of the school (Ebersohn, 2017). The alarming factor includes overcrowded classrooms in rural schools and the cases of notorious students bringing drugs into the schools for other students to buy. There are cases where children come to school smelling weed or alcohol and with dangerous weapons (Hewitt, 2016). There are also cases of leakages in the classrooms and school building which affects teaching and learning especially whenever it rains. Mostly, the classrooms get flooded which sometimes result in closure of lessons or in extreme cases, schools are compelled to dismiss (Ebersohn, 2017). The poverty that affects rural schools cannot be curbed without bringing development to the places (Okoye, 2013). This does not suggest that the government is irresponsive rather it points to the existence of development and policy implementation deficiency.

\section{Policies Implementation Strategies And Deficiencies:}

The government has executed some strategies to reducing poverty effects in schools and ensure quality education for all. The strategies including feeding scheme, free education, free resources and study materials, free transportation, free stationaries and child grant. (a) School feeding scheme: Nhapo et al. (2015) research study on accessing the quality of food served under South African school feeding scheme shows possible nutritional benefits and deficiencies in most rural schools. The school feeding scheme also known as the National School Nutrition Programme aims to foster better quality education by enhancing children's active learning capacity, alleviating short-term hunger, providing an incentive for children to attend school regularly and promptly; and addressing certain micro-nutrient deficiencies (Nhlapo et al., 2015). The school feeding scheme is part of the Integrated Food Security Strategy for South Africa, which was introduced in 2002. It involves other departments such as Departments of Health, Social Development, Land Affairs and Agriculture. The school feeding program responds to nutritional needs, poor nutrition, hunger or food security facing rural communities (Pearce, 2016). The scheme targets Grade R up to Grade 7 although not all children entitled to school feeding received food. Also, the food nutritional efficiency remains undetermined because the food scheme inspectors seldom come to the rural areas (Nhlapo et al., 2015). The inspectors focus on township and urban public schools due to accessibility impediments associated with going to the rural communities.

Recently, parents talk of food disappearing from schools and in some cases, there has been corruption and theft by people providing the food (Black \& Engle, 2008). In many areas, there is no system of accountability given rural circumstances. During rainy days the bread truck that deliver bread to rural schools get stacked on the muddy road. The milkshakes require water and schools without portable water reported children with diarrhea. The younger children under six who are not yet at school cannot access food through the program (Hewitt, 2011). The scheme happens to feed even the poor caregivers, cooks and school staff which put strain on the meals meant or provided for the children (Nhlapo et al., 2015). The feeding scheme strategy only feeds the child at the school which has been criticized as being inadequate since some children only have proper meal at school. (b) Free education: The South African School Act, 1996 provides for a free elementary and high school education for South African citizens especially those from previously disadvantaged background. The same Act (1996) also provides for equitable funding of schools (Act No. 84 of 1996). The South African Schools Act (1996) also aims to provide a uniform system 
for the organization, governance, funding of schools, review and repeal certain laws relating to schools (Act No. 84 of 1996). Apparently, the South African education is governed by two national departments namely department of basic education (DBE), which is responsible for primary and secondary schools and the department of higher education and training (DHET), which is responsible for tertiary education and vocational training (Ladd, 2012; Ebersohn, 2017). The DBE deals with public schools, private schools, early childhood development (ECD) canters, and special needs schools. Hence, public schools and private schools are collectively known as ordinary schools and comprise roughly 97\% of schools in South Africa (Omarjee, 2017). The DHET deals with further education and training (TVET) colleges, adult basic education and training (ABET) centers, and higher education (HE) institutions. In South Africa education is hoped to reduce poverty, boosts economic growth and increases income, enhance healthy life, reduces maternal deaths, and combats diseases such as HIV and AIDS (Nhlapo et al., 2015). South Africa is one of the nations with highest rates of public investment in education in the continent, as well as globally, yet the country is far from actualizing its priority (Ladd, 2012). Unemployment is rife among rural dwellers and the youth.

Meanwhile, the rural students are faced with the risk of becoming like their unemployed parents. Thus, a vicious circle of poverty persists if nothing is done to prevent such recycling of poverty (Pearce, 2016). (c) Free resources: amongst government's poverty interventions programmes includes the provision of infrastructure, construction of roads and building of new schools in the rural communities (Taylor \& Servass van der Berg Ronelle Burger, 2011). Whilst the rural school students are provided with food, stationaries, and desk to support teaching and learning; the departments officials often monitor the use of these resources in schools (Ebersohn, 2017). According to Pearce (2016), the four variables essential for excellent education include prioritizing teaching and learning; a good partnership between home, school, and community; and excellent school leadership and teachers (Pearce, 2016). According to Pearce (2016), the resources provided by the government is of immense assistance to the rural areas of South Africa. There are also the distribution initiatives such as sanitary pads, toiletries and condoms in rural schools. Despite these government's efforts there is still high rate of HIV and AIDS, pregnancy rate, and poverty rate in KwaZulu-Natal province. It happens sometimes that the resources provided or distributed by the government are either insufficient or delayed although where there is insufficiency, parents are asked to assist here and there. Thus, the situation which poor or unemployed parents consider burdensome. (d) Free transportation: government also provides rural students with school transport (Fick, 2017). It is difficult to teach a child who walked an hour or more to school (Dike, 2017). The child is exhausted and need time to recuperate, hence the reality of rural dwellers. According to the statistics, more than double the number of children in cities use taxis to school rather than buses and half of the children in the highest income group are taken to school by car (Statssa, 2016; Fick, 2017). Whilst most rural students walk between 30 to 60 minutes to school. This means that some students are walking more than 3 to $6 \mathrm{~km}$ daily! These students are often overloaded with books and heavy backpacks which also have an impact on their energy levels (Safer parenting, 2015; Omarjee, 2017). The Department or Education has collaborated with the Department of Transport to ensure provision of transport for Gr R to Gr 12 students who walk approximately $3 \mathrm{~km}$ to rural schools. It is important to acknowledge that the provision of transport has relieved burden, promotes excellence, and ensure safety (or protection) for rural children (Hewitt, 2011). There are bureaucratic concerns though; the bureaucracy for providing social services by public sectors in rural places is a concern (Berg, Taylor \& Burger, 2011). For instance, the school children are often denied of transport because the transportation contracts have elapsed or not signed on time. The buses may be broken down and not fixed on time.

This study is non-empirical research relies on empirical research literature. This include the review of existing literature with reference to relevant research studies, journals, textbooks, refereed conference papers, and dissertations. Thus, the study does not need to be data driven because it has been well researched. The following findings accrued from the study.

\section{The Study Findings:}

The study's findings are arranged in themes and presented using the sub-research questions. These questions include (a) What are the effects of poverty on the emotional well-being of elementary school students? The literature reviewed show that poverty has enormous effects on the emotional well-being of elementary students or children in South Africa. The effects include (i) Poor concentration: Dike (2017) highlighted that children concentration (or brain function) can be affected by poverty and hunger of which can lead to lower brain function. (ii) Lowers brain function is also identified as a major poverty effect which hampers 
the emotional well-being of the school children. Woolfolk (2016) claims that poverty has direct correlation to the children's brain function. (iii) Down syndromes also stood out in the overall literature reviewed by the researcher. For instance, Dike (2017) and Tang et al. (2016) each highlighted that depression, lack of concentration in classrooms, low performance, low participation, stress, trauma and other illness-related symptoms are being noticed on rural school children. Thus, these syndromes are peculiar to children from poor homes. The symptoms combine to exacerbate the physical and mental state disposition unanimously described by these authors as down syndromes (Dike, 2017; Tang et al., 2016). The consequences of the above ailments or down syndrome on the school children results in increased absenteeism and dropouts (Carey, 2014). Dike (2017) corroborated the claims that poverty causes increased absenteeism of the affected children. Thus, the dropping out of the students re-enforces poverty and has direct correlation to the increased crime rate, inmates and youth unemployment in the country. This raises the question of whether it is possible to actualize the national vision of equal education in South Africa. (b) How effective are the poverty alleviation strategies in reducing the poverty effects on the emotional well-being of school children? The literature review revealed that the feeding scheme has ongoing limitations or unresolved defects. (i) Transportation problems: Fick (2017) affirmed that the transports provided by the government's poverty alleviation strategy are unable to convey all students and has been limited to children travelling within certain kilometers. This creates an unfair situation for other children and leaves them traumatized and reluctant to school. (ii) Feeding scheme limitations: Nhlapo et al. (2015) and Pearce (2016) emphasized that feeding scheme has two critical limitations which include poor school meals or poor nutritional meal. Nhlapo et al. (2015) mentioned that in extreme cases school children are provided insufficient meals. Pearce (2016) claims that most times the meals are nutritionally deficient. (iii) Insufficient provision of resources: the issues of inconsistency and limited resource came up from the literature reviewed. Ebersohn (2017) stated that government provision of resources was indeed inconsistent which includes supplies of stationeries, sanitary pads and school uniforms. Taylor \& Servass van der Berg Ronelle Burger (2011) re-affirmed that sometimes resources were delayed and inconsistent with school children's preference. Ladd (2012) mentioned that public schools have been poorly funded. (c) What are the limitations of the poverty alleviation strategies to the well-being of the students? The literature review also highlighted that (i) Parents are burdened and children are partially relieved: the children ended up losing focus especially when noticing their parents' struggle in trying to finance their upkeep (Ebersohn, 2017). (ii) Affects classroom teaching and learning: Dike (2017) and Tang et al. (2016) stressed that poor performance and concentration detracts from proper classroom teaching and learning such that it denies the teacher from achieving optimum goals for teaching and learning. For instance, Okoye (2013) emphasized that understanding the language of teaching and learning becomes difficult for a hungry student. (iii) Corruption and theft: Black \& Engle (2008) complained that school management, teachers and parents often talk of food disappearing from schools. Gorski (2013) reaffirms that the implementers were part of the problems as most facilities are vandalized while other things ended up being stolen or destroyed by the beneficiaries. Thus, the allocated resources sometimes get lost and never reached the students or school children. (d) How can the strategies be improved to ensure equity and excellence for all students in the (rural) classroom? The literature reviewed pointed out several improvement options such as: (i) Constant evaluation and monitoring of the strategies: Nhlapo et al. (2015) called for constant evaluation and monitoring of the strategies according to different or specific contexts. The implementation process of each strategy must be intensified and monitored regularly (Gorski, 2013). (ii) Proper accountability on use of resources: Pearce (2016) agreeing with others added that good partnership between parents, school and community would breed more excellent leadership would enhance accountability process and reduce abuse of resources. (iii) Bureaucratic processes need to be reviewed: Berg, Taylor \& Burger (2011) blamed bureaucratic processes for the inefficiency and most implementation challenges of the poverty alleviation strategies in schools. Thus, the bureaucratic process of delivering social services in South Africa needs to be shortened, reviewed and refined. (iv) Need for more social workers: Safer parenting (2015) also blamed lack of proper inspection and inadequate attention given to students in rural public schools. Thus, this situation does not only require deploying more social workers, but the government must recognize and act accordingly towards the immense need for more consolidated and efficient social work process. (v) Improve rural infrastructures \& farming practices: improvement of the rural infrastructures and building school hostels where needy students can receive proper attention were raised (Hewitt, 2016). This includes the improvement of school infrastructure, construction of rural roads, building of new schools and fund 
farming initiatives for the people in the rural areas (Taylor \& Servass van der Berg Ronelle Burger, 2011; Nhlapo et al., 2015).

\section{Recommendations And Conclusion}

The efforts of the government if valued by the people would have assisted in a vast shift in the development of several other projects like more school buildings. The problem is the resources available are being mismanaged and destroyed by the inhabitants (Fick, 2017; Ebersohn, 2017; Gorski, 2013). The government fiscal is under serious strain, corporations, NGOs and charity organizations need to come on board. The Reconstruction and development program (RDP) houses are insufficient to cater for people in the rural areas (Gorski, 2013). Thus, the children risk contacting diseases from using bucket toilets. In some instances, there can be outbreak of diarrhea and cholera. Preferably, the government can disburse funding for the rural people to enter and improve farming practices (Nhlapo et al., 2015). The government may offer the necessary and required help to the students but with increased unemployment rate the government initiatives is continuously neutralized. The government may provide enormous resources, but the problem needs a broader approach. Thus, the non-governmental organizations and non-profit companies in Kwazulu-Natal must assist school children with resources such as textbooks, school uniforms, sanitary pads, voluntary teaching, TV learning programmes, extra-teaching professionals and entrepreneur capacitation training to help reduce the effect of poverty (Gorski, 2013). There is an increasing importance for more Corporate social investment (CSI) programs. Highly profitable companies in the South African regions where poverty is highly predominant should come up with initiative to build schools, provide bursaries and give out accessories like computers, calculators, and school buildings to students with high poverty rate. Pearce (2016) recommended a stringent accountability process that includes inspectors that comes from the same area with the benefiting students.

5.1 Recommendations for Covid-19: In South Africa the study days in basic education is alternated to allow possible observation of Covid-19 restrictions, even though low transmission is reported among younger children. Except cases of teachers and few learners, there is limited cases reported of outbreak especially in junior schools. However, children can be carriers (WHO, 2020). The schools must ensure adequate ventilation and increase airflow spaces. The schools must improve their cleanliness, ensure students have sanitizer, basing and soap for washing their hand. The DBE should consider school-related public health measures in the context of Covid-19. Only under 5years children should not be required to wear mask, but teachers and support staff must wear mask especially when in widespread transmission areas or when they cannot guarantee at least 1-metre distance from others (WTO, 2020). The children from underprivileged communities and unemployed parents who observe study-day rotation need to share from the food scheme, the government need to figure out how to make this possible.

In conclusion, the state, non-governmental organizations and privately-owned companies need to partner to address poverty problem in the country. Thus, the addressing of the problems faced by poor children in the rural Kwazulu-Natal required a wider approach beyond the current efforts to assist the rural children.

\section{References}

1. Alexander, R. (2010). The impact of poverty of African American children in the child welfare and Juvenile Justice Systems. College of social work: Ohio State.

2. Berg, S.V., Taylor \& Burger, R. (2011). Improving Education Quality in South Africa. Department of Economics. University of Stellenbosch. http://www.resep.sun.ac.za/wpcontent/uploads/2012/10/2011-Report-for-NPC.pdf

3. Black, M.M., \& Engle, P. L. (2008). The effect of poverty on child development and educational outcomes. https://www.ncbi.nlm.nih.gov/pubmed/18579886.

4. Carey, B. (2014). How we learn: the surprising truth about when, where, and why it happens. United States of America: Penguin Random House Company.

5. Dike, V. E. (2017). Poverty and Brain Development in children: Implications for learning. Asian Journal of Education and Training, 3(1), 64-68.

6. Ebersohn, L. (2017). A resilience, health and well-being lens for education and poverty. South African Journal of Education, 37(1), 1-9.

7. Fick, A. (2017). Poverty in South Africa. http://www.statssa.gov.za/?p=10334. 
8. Global partnership for education. (2017). Education is a vital human right and plays a key role in human, social, and economic development. https://www.globalpartnership.org/education.

9. Gorski, P.C. (2013). Building a pedagogy of engagement for students in poverty. George Mason University: Fairfax, Va.

10. Hewitt, P. M. (2011). Teaching with poverty in mind: What being poor does to Kids' Brains and What Schools can do about it. Arlington: American Association of School Administrators. http://cupdx.idm.oclc.rog/login?url=https://search.proquest.com/docview/859370700?accountid=102 48.

11. Ladd, H. F. (2012). Education and poverty: confronting the evidence. Journal of Policy Analysis and Management, 00(0), 1-25.

12. Mueller, M.P., Bovaird, S., \& Ferguson, H. B. (2007). The impact of poverty on educational outcomes for children. Paediatr Child health, 12(8), 701-706.

13. Nhapo, N., Groenewald, H.W., Kativu, E., \& LuesRyk, J. F. (2015). Accessing the quality of food served under South African school feeding. www.sajs.co.za/...south-african...feedingscheme.../nthabiseng-nhlapo-ryk-j-f-lues-ed.

14. Okoye, F. I. (2013). The use of language in Mainstream Grade 4 schools in Kwazulu-Natal: Implications for Policy development, a dissertation submitted for the degree in Master of Education. University of KwaZulu-Natal: KwaZulu-Natal.

15. Omarjee, L. (2017). More than 50\% South African population is living in poverty. Retrieved from: https://www.fin24.com/.../more-than-50-of-sas-population-is-living-in-poverty-20170...

16. Pearce, J. (2016). Living on the edge. Rethinking poverty, social class and schooling. Journal of Educational Administration and History, 48(1), 122-124. http://dx.doi.org/10.1080/00220620.2015.1034979.

17. Rury, J. L., \& Jennifer, C. (2006). Poverty and Education: A critical analysis of the Ruby Payne phenomenon. Teachers college record.

18. Safer parenting. (2015). School transportation policy in South Africa. https://www.saferschools.co.za/school-transportation-policy/

19. Statistics South Africa (Stats SA). (2016). https://www.statssa.gov.za/?p=10334.

20. Tang Hang Man Esther, Scarlet fung Oi Poon, \& Siu Mui Chan. (2016). Daily hassles, cognitive emotion regulation and anxiety in children. Vulnerable Children and Youth Studies 11(3), 238-250. http://scholar.google.co.za/scholar?hl=en\&as.

21. Taylor \& Servass van der Berg Ronelle Burger. (2011). Low quality education as a poverty trap. Working paper 25/2011. Stellenbosch University, department of Economics.

22. Tissington, L. D., \& Lacour, M. (2011). The effects of poverty on academic achievement. Educational research and reviews 6(7), 522-527. http://www.academicjournals.org/ERR.

23. Woolfolk, A. (2014). Educational psychology: Active learning edition. $12^{\text {th }}$ Edn. San Francisco, CA: Pearson Education, Inc.

24. World Health Organization. (2020, September). Corona disease (COVID-19): Schools. $Q \& A s$. https//www.who.int/covid-19/schools 